\title{
A Study on Vitality and Happiness Levels of Sports High School Students
}

\author{
Ömer Faruk Yazıcı (Corresponding author) \\ Faculty of Sports Science, Tokat Gaziosmanpaşa University, Tokat, Turkey \\ Tel: 90-544-942-2878Ｅ-mail: o-farukyazici@hotmail.com
}

Mustafa Barış Somoğlu

Ministry of National Education, Physical Education and Sports Teacher, Artvin, Turkey

Tel: 90-554-320-8002Ｅ-mail: barissomoglu@gmail.com

Received: November 5, $2021 \quad$ Accepted: December 1, 2021

Published: December 31, 2021

doi:10.5296/jei.v7i3.19274 URL: https://doi.org/10.5296/jei.v7i3.19274

\begin{abstract}
The present study is aimed at determining subjective vitality and subjective happiness levels of sport high school students and to examine the levels based on certain variables. Relational screening model was used in this study. The sample of the research consisted of a total of 185 students, $113(61.1 \%)$ male and $72(38.9 \%)$ female, who continued their education at "Trabzon Sports High School" in 2019-2020. "Personal Information Form" designed by the researcher, "Subjective Vitality Scale (SVS)" and "Subjective Happiness Scale (SHS)" were used as data collection tools in the research. It was accepted that the research data showed a normal distribution according to the skewness and kurtosis values. Accordingly, descriptive statistics were used as a statistical method in the analysis of the data, and T-Test, one-way analysis of variance (ANOVA), correlation and regression analyzes were used for independent groups.

In line with the research analysis, it was found that the students of sports high schools had above-average levels of vitality and happiness. It has been observed that the subjective vitality and happiness levels are higher among male students and students affiliated with a sports club (licensed/unlicensed). In addition, it was concluded that the subjective happiness and vitality levels are higher among students who do team sports and those who have longer years of practising sports, and no significant difference was determined according to the variable of socio-economic status of the family. As a result, it was found that there was a high (.81) significant positive correlation between subjective happiness and vitality. Another important
\end{abstract}


result is that subjective vitality $(66 \%)$ has an important role in predicting subjective happiness.

Keywords: Student, Sports high school, Happiness, Vitality

\section{Introduction}

The factors underlying human behavior have been the subject of research for centuries and the concept of happiness has generally been encountered as an answer to this question (Diener, 1984). Seeking happiness is in the nature of every person (Yalçın, 1994). In recent years, intense work tempo, working conditions, stress, anxiety and technological developments have brought the concept of happiness to the fore. Thus, the phenomenon of being happy, needed due to the negative reasons brought about by the present day (Baysal \& Aka, 2013), brought along many questions as to the definition and nature of happiness, what the determining factors are, and whether there is permanent happiness or not, and answers to those questions were sought (Lyubomirsky, Sheldon, \& Schkade, 2005).

Previous studies have generally dealt with negative emotional states, and positive situations affecting happiness have been ignored (Goleman, 2003; cited in Çelik, 2008). After the 1970s, studies on positive emotions increased, and the studies into negative situations were criticized (Yetim, 2001). With the positive psychology movement, both social and behavioral scientists have created an experimental and institutional structure on psychological well-being, and the subject of happiness has begun to be examined within the framework of a scientific structure (Diener, 1984; Türkdoğan, 2010). Positive psychology, which focuses on the positive aspects of people, stated that the individual should actualize himself at the highest level. Concepts such as life satisfaction, subjective well-being, psychological well-being, psychological resilience, and personal development have begun to appear in the literature (Csikszentmihalyi, 2005).

According to Diener (1984), who defines happiness as the emotional evaluation of experiences, it is stated that the frequent occurrence of positive mood states, the rare occurrence of positive emotional states, and as a result, the high satisfaction from their lives is an indicator of happiness. Studies have shown that happy individuals feel better, have better interpersonal relationships thanks to more intense positive emotions (Diener \& Seligman, 2002), and life energies are better, their life spans are longer and they are more successful in their business lives (Lyubomirsky, King, \& Diener, 2005). Psychological well-being, which makes life better and is a state that individuals should develop for their mental well-being and health, is a condition that individuals do not consciously focus on, but always feel (Yazıcı \& Tunçkol, 2015). In other words, it is the general state of the individual's perspective of life. The concept of vitality, which is also called the quality of life, is thought to be related to happiness.

It is thought that individuals who are fit can be healthier and happier. The basis of the concept of vitality is based on the "Self-Determination Theory" and it is an important part of subjective well-being and happiness, which is a part of positive psychology, and is an important feature to have (Akın, 2012; Ryan \& Frederick, 1997). Subjective vitality, predicting a positive structure, can be expressed as a subjective experience of being energetic, 
vital and fit (Ryan \& Frederick, 1997). According to W. Hoeger and S. Hoeger (2012), wellness is defined as the individual's creating a lifestyle, leading a healthy and quality life, the art of evaluating his life as a whole, and feeling wellness. In order to be happy, fit and to have a positive outlook on their lives, individuals get rid of negative emotions and include positive ones. Determining the factors that negatively affect happiness and well-being, and taking measures to prevent those factors will make individuals fitter and happier.

With the idea that "productive societies consist of healthy, happy and fit individuals", the health and well-being of today's children and youth is closely related to the future of society (Taşer, 2004). It is thought that the concepts of happiness and well-being concern all humanity from past to present, as well as sports high school students who are at the very beginning of their sports life. In the light of this, determining the vitality and happiness levels of students studying in sports high schools and examining them based on certain variables constitute the research problem.

\section{Method}

\subsection{Research Model}

This research was conducted with a descriptive survey model. In this method based on describing the past or present situation as it is, the situation, person or object to be investigated is to be described in its own conditions and observed in its existing situation without changing it (Karasar, 2012).

\subsection{Research Group}

The study group of the research consisted of a total of 185 students of whom $113(61.1 \%)$ males and $72(38.9 \%)$ females studying at Trabzon Sports High School affiliated to the Ministry of National Education in the 2019-2020 academic year.

\subsection{Sampling Procedures}

In determining the research group, "Convenience Sampling" method was used, in which the sample is taken from existing and volunteering individuals in the immediate and easily accessible vicinity if it does not cover a region in question. If the researcher can reflect the range of variables measured to his sample as much as possible and the variables to be examined include basic human characteristics, a region, country, etc. sampling may not be necessary (Erkuş, 2009). In addition, this method is time-effective and brings practicality to the researcher (Şimşek \& Yıldırım, 2004).

The "Subjective Vitality and Subjective Happiness Scale" used in the research was collected from the students at Trabzon Sports High School, who formed the study group in the 2019-2020 academic year. Prior to the implementation of the data collection tools, necessary permissions were obtained. Considering the number of students, the questionnaires were reproduced, the appropriate time interval was determined within the knowledge of the school administration, and the questionnarries were applied with the help of the school counselor and physical education teacher. The rules to be complied with were specified in detail and the voluntary basis was adhered to. Out of the 200 applied questionnaires, those that did not have 
proper coding were ruled out and 185 valid questionnaires were included in the statistical analysis.

\subsection{Data Collection Tools}

The "Personal Information Form" designed by the researcher, the "Subjective Vitality Scale (SVS) and Subjective Happiness Scale" (SHS) were applied to determine the vitality and happiness levels of individuals.

\subsubsection{Subjective Happiness Scale (SHS)}

The "Subjective Happiness Scale", developed by Lyubomirsky and Lepper (1999) and adapted into Turkish by Akın and Satıc1 (2011), was used to determine the happiness levels of the students participating in the study. The scale, adapted into Turkish, is a 7-point Likert scale (1 I am not happy at all-7 I am very happy) and consists of 4 items. The 4th item of the scale is reverse coded. High scores obtained from the scale indicate that the individual's subjective happiness level is higher. In the reliability analyzes of the Subjective Happiness Scale, the Cronbach $\alpha$ reliability coefficient was found to be .86 . The Cronbach $\alpha$ internal consistency coefficient calculated on the data collected within the scope of this research was calculated as .94 .

\subsubsection{Subjective Vitality Scale (SVS)}

The "Subjective Vitality Scale" (SVS), developed by Ryan and Frederick (1997) and adapted into Turkish by Akın, Satıc1, Arslan, Akın, and Kayıs (2012), was used to determine the vitality levels of sports high school students. The scale, adapted into Turkish, is a 7-point Likert scale ( 1 not valid-7 completely valid) and consists of 7 items. The second item of the scale is reverse coded. High scores obtained from the scale indicate that the individual's subjective vitality level is higher. In the reliability analyzes of the Subjective Vitality Scale, the Cronbach $\alpha$ reliability coefficient was found to be .84 . The Cronbach $\alpha$ internal consistency coefficient within the scope of this research was found to be .93 .

\subsection{Analysis of Data}

The data collected from the research group were interpreted with the statistical package program SPSS 24. SPSS Inc., Chicago, Illinois, USA. Before the analysis -the data was checked with the values of Skewness and Kurtosis (normal distribution of the data) whether the parametric tests met the prerequisites, and it was seen that the data showed a normal distribution. Thus, parametric tests were used in the analysis. Descriptive statistics (frequency, arithmetic mean, standard deviation) were used as the statistical method, T-Test and one-way analysis of variance (ANOVA) for independent groups, Tukey HSD comparison tests to determine the intergroup differences, Simple Linear Pearson Correlation analysis and Regression test to determine the relationship between the scales. 


\section{Results}

Table 1. Distribution of individuals' personal information (n: 185)

\begin{tabular}{|l|l|l|l|}
\hline \multirow{3}{*}{ Gender } & & $\mathrm{f}$ & $\%$ \\
\hline \multirow{3}{*}{ Affiliated with a Sports Club (Licensed) } & Female & 72 & 38.9 \\
\cline { 2 - 4 } & Male & 113 & 61.1 \\
\cline { 2 - 4 } & Yes & 102 & 55.1 \\
\hline \multirow{3}{*}{ Sports Branch } & No & 83 & 44.9 \\
\hline \multirow{3}{*}{ Years of Practise } & Individual & 98 & 53.0 \\
\hline \multirow{3}{*}{ Family Income } & $1-5$ years & 145 & 47.0 \\
\cline { 2 - 5 } & $6-10$ years & 40 & 21.6 \\
\hline & Income < Expense & 71 & 38.4 \\
\cline { 2 - 5 } & Income $=$ Expense & 82 & 44.3 \\
\cline { 2 - 4 } & Income $>$ Expense & 32 & 17.3 \\
\hline
\end{tabular}

Table 2. Scores obtained from the scales

\begin{tabular}{|l|l|l|l|l|l|l|}
\hline & Number of Items & $\mathrm{n}$ & $\overline{\mathrm{x}}$ & $\mathrm{SD}$ & Skewness & Kurtosis \\
\hline SVS & 7 & 185 & 3.97 & 1.82 & .193 & -.893 \\
\hline SHS & 4 & 185 & 3.81 & 2.02 & .338 & -1.219 \\
\hline
\end{tabular}

Table 2 shows the arithmetic mean, standard deviation values, skewness and kurtosis values related to the scores obtained from the items from the Subjective Vitality Scale (SVS) and Subjective Happiness Scale (SHS). The arithmetic mean and standard deviation of the scores obtained from SVS are 3.97 \pm 1.82 . The arithmetic mean and standard deviation of the scores obtained from SHS are 3.81 \pm 2.02 . The skewness and kurtosis values related to whether the total scores obtained from SVS and SHS fulfill the assumption of normality were calculated as $0.193 /-0.8930 .338 /-1.219$, respectively. It is seen that the data obtained from SVS and SHS satisfy the assumption of normal distribution. 
Table 3. T-Test results of SVS and SHS scores by gender variable

\begin{tabular}{|l|l|l|l|l|l|l|l|}
\hline & Gender & $\mathrm{n}$ & $\overline{\mathrm{x}}$ & $\mathrm{SD}$ & $\mathrm{df}$ & $\mathrm{t}$ & $\mathrm{p}$ \\
\hline \multirow{3}{*}{ SVS } & Female & 72 & 3.40 & 1.61 & \multirow{2}{*}{166.356} & -3.557 & \multirow{2}{*}{$0.00^{*}$} \\
\cline { 2 - 6 } & Male & 113 & 4.32 & 1.86 & & & \\
\hline \multirow{2}{*}{ SHS } & Female & 72 & 3.17 & 1.81 & \multirow{2}{*}{164.480} & -3.656 & $0.00^{*}$ \\
\cline { 2 - 6 } & Male & 113 & 4.22 & 2.05 & & & \\
\hline
\end{tabular}

In the analysis of the gender of the students, a significant difference was found between the scores of Subjective Vitality $\left[\mathrm{t}_{(166.356)}=-3.557, \mathrm{p}<0.01\right]$ and Subjective Happiness $\left[\mathrm{t}_{(164.480)}=\right.$ $-3.656, \mathrm{p}<0.01]$ in favor of male students (Table 3 ).

Table 4. T-Test results of SVS and SHS scores by the variable of being affiliated with a sports club

\begin{tabular}{|l|l|l|l|l|l|l|l|}
\hline & Affiliated with a Sports Club & $\mathrm{n}$ & $\overline{\mathrm{x}}$ & $\mathrm{SD}$ & $\mathrm{df}$ & $\mathrm{t}$ & $\mathrm{p}$ \\
\hline \multirow{3}{*}{ SVS } & Yes & 102 & 4.48 & 1.73 & \multirow{2}{*}{183} & \multirow{2}{*}{4.453} & \multirow{2}{*}{$0.00^{* *}$} \\
\cline { 2 - 9 } & No & 83 & 3.34 & 1.73 & & & \\
\hline \multirow{3}{*}{ SHS } & Yes & 102 & 4.56 & 1.97 & \multirow{2}{*}{182.360} & \multirow{2}{*}{6.183} & \multirow{2}{*}{$0.00^{* *}$} \\
\cline { 2 - 9 } & No & 83 & 2.89 & 1.69 & & & \\
\hline
\end{tabular}

The T-Test results as to being affiliated with a sports club and SVS and SHS show that there are differences in favor of the students who are affiliated with the sports club $\left[\mathrm{t}_{(183)}=4.453, \mathrm{p}\right.$ $<0.01],\left[\mathrm{t}_{(182.360)}=6.183, \mathrm{p}<0.01\right]$. In other words, subjective vitality and happiness levels changed depending on doing sports (Table 4).

Table 5. T-Test results of SVS and SHS scores according to sports branch variable

\begin{tabular}{|l|l|l|l|l|l|l|l|}
\hline & Sports Brach & $\mathrm{n}$ & $\overline{\mathrm{x}}$ & $\mathrm{SD}$ & $\mathrm{df}$ & $\mathrm{t}$ & $\mathrm{p}$ \\
\hline \multirow{3}{*}{ SVS } & Team & 98 & 4.43 & 1.76 & \multirow{2}{*}{183} & \multirow{2}{*}{3.828} & \multirow{2}{*}{$0.00^{* *}$} \\
\cline { 2 - 6 } & Individual & 87 & 3.44 & 1.74 & & & \\
\hline \multirow{3}{*}{ SHS } & Team & 98 & 4.46 & 1.98 & \multirow{2}{*}{182.822} & \multirow{2}{*}{4.991} & \multirow{2}{*}{$0.00^{* *}$} \\
\cline { 2 - 6 } & Individual & 87 & 3.07 & 1.81 & & & \\
\hline
\end{tabular}




\section{Macrothink}

As can be seen in Table 5, a significant difference was determined between the students' SVS $\left[\mathrm{t}_{(183)}=3.828, \mathrm{p}<0.01\right]$ and SHS $\left[\mathrm{t}_{(182.822)}=4.991, \mathrm{p}<0.01\right]$ scores of those who do team sports compared to those who do individual sports. In other words, the happiness and vitality averages were found higher in team athletes.

Table 6. T-Test results of SVS and SHS scores according to years of practice variable

\begin{tabular}{|l|l|l|l|l|l|l|l|}
\hline & Years of Practice & $\mathrm{n}$ & $\overline{\mathrm{x}}$ & $\mathrm{SD}$ & $\mathrm{df}$ & $\mathrm{t}$ & $\mathrm{p}$ \\
\hline \multirow{3}{*}{ SVS } & $1-5$ years & 145 & 3.75 & 1.78 & \multirow{2}{*}{183} & \multirow{2}{*}{-3.161} & \multirow{2}{*}{$0.00^{* *}$} \\
\cline { 2 - 6 } & 6 years and more & 40 & 4.75 & 1.75 & & & \\
\hline \multirow{2}{*}{ SHS } & $1-5$ years & 145 & 3.51 & 1.98 & \multirow{2}{*}{183} & -4.031 & $0.00^{* *}$ \\
\cline { 2 - 6 } & 6 years and more & 40 & 4.91 & 1.81 & & & \\
\hline
\end{tabular}

Analysis results revealed a significant difference in terms of years of practising sports between the students' SVS [ $\left.\mathrm{t}_{(183)}=-3.161, \mathrm{p}<0.01\right]$ and SHS $\left[\mathrm{t}_{(183)}=-4.031, \mathrm{p}<0.01\right]$ scores (Table 6).

Table 7. ANOVA Results of SVS and SHS scores according to the variable of family income

\begin{tabular}{|c|c|c|c|c|c|c|c|}
\hline & Family Income & $\mathrm{n}$ & $\bar{x}$ & SD & $\mathrm{df}$ & $\mathrm{F}$ & $\mathrm{p}$ \\
\hline \multirow{3}{*}{ SVS } & Income $<$ Expense & 71 & 4.03 & 1.99 & \multirow{3}{*}{$2-182$} & \multirow{3}{*}{1.162} & \multirow{3}{*}{.315} \\
\hline & Income $=$ Expense & 82 & 3.77 & 1.68 & & & \\
\hline & Income $>$ Expense & 32 & 4.33 & 1.74 & & & \\
\hline \multirow{3}{*}{ SHS } & Income $<$ Expense & 71 & 3.85 & 2.11 & \multirow{3}{*}{$2-182$} & \multirow{3}{*}{.075} & \multirow{3}{*}{.928} \\
\hline & Income $=$ Expense & 82 & 3.74 & 1.98 & & & \\
\hline & Income $>$ Expense & 32 & 3.89 & 1.99 & & & \\
\hline
\end{tabular}

According to the ANOVA results of whether the family income status shows a significant difference in SVS and SHS scores, it was determined that there was no significant difference between the students' $\operatorname{SVS}\left[\mathrm{F}_{(2.182)}=1.162, \mathrm{p}>0.05\right]$ and SHS scores $\left[\mathrm{F}_{(2.182)}=0.075, \mathrm{p}>\right.$ 0.05] (Table 7). 
Table 8. Correlation results between SVS and SHS

\begin{tabular}{|l|l|l|l|}
\hline \multirow{2}{*}{} & \multicolumn{3}{|c|}{ SVS } \\
\cline { 2 - 4 } & $\mathrm{n}$ & $\mathrm{r}$ & $\mathrm{P}$ \\
\hline SHS & 185 & 0.81 & $0.00^{* *}$ \\
\hline
\end{tabular}

Pearson Correlation test results are provided in Table 8 to test the relationship between subjective vitality and subjective happiness. In the correlation analysis, it was determined that there was a positive and significant relationship between subjective vitality and subjective happiness $(\mathrm{r}=0.81, \mathrm{p}=0.00)$.

Table 9. Regression results between SVS and SHS

\begin{tabular}{|l|l|l|l|l|l|}
\hline & $\mathrm{B}$ & Standard Error & $\beta$ & $\mathrm{t}$ & $\mathrm{P}$ \\
\hline Constant & .234 & .211 & & 1.113 & .267 \\
\hline SVS & .902 & .048 & .810 & 18.671 & .000 \\
\hline
\end{tabular}

Note. $\mathrm{R}=0.81 ; \mathrm{R}^{2}=.656 ;\left[\mathrm{F}_{(1.183)}=348.594, \mathrm{p}=0.00\right]$.

As can be seen in Table 9, the result of the regression analysis determined that the subjective vitality levels of the athlete students were a significant predictor of their subjective happiness. There is a highly significant positive correlation $(R=0.81)$ between the subjective vitality and subjective happiness of the athlete students. Students' subjective vitality explains $66 \%$ of the total variance of their subjective happiness.

\section{Discussion}

In this section, the subjective happiness and subjective vitality of sports high school students are discussed through the findings in the literature, the results are interpreted and summarized.

The subjective happiness (3.81 \pm 2.02$)$ and subjective vitality levels $(3.97 \pm 1.82)$ of sports high school students are above the average. It can be explained by the fact that sports high school students spend a lot of time on sports and physical activities. It is stated that participation in sports reduces many health problems such as heart diseases, obesity, etc., and increases conditions such as well-being, happiness and quality of life (Rejeski, Shelton, Miller, Dunn, King, and Salls, 2001). It is stated that participation in physical activity has positive effects on mood and increases subjective well-being (Fox, 1999; Tuzgöl-Dost, 2006). Yazıc1 and Tunçkol (2015) revealed similar results in their research on physical education teacher candidates.

According to the findings obtained in the study, the subjective vitality and subjective happiness levels of sports high school students differ in favor of male students (Table 3). In a 
study examining the relationship between participation in sports and happiness in the USA, it was stated that both genders were happy to participate in physical activity, but boys scored higher than girls from participating in sports (Huang \& Humphreys, 2012). In many studies that overlap with the research findings, it is reported that boys had life satisfaction, subjective well-being, psychological well-being and happiness (Somoğlu, 2016; Doğan, 2004; Aşç1, 2002; Yazıc1, Caz, \& Tunçkol, 2016). Contrary to these findings, it was observed that the subjective well-being (Sezer, 2011) levels of the participants in favor of girls were higher than that of men. There are studies in the literature in which gender does not have an effect on happiness (Diener \& Myers, 1997; Kimball \& Willis, 2006). The absence of a significant difference between the well-being scores of girls and boys was reported in some studies (Cirhinlioğlu, 2006; Gürgan, 2014; Çağrı \& Gürgan, 2010; Mahon et al., 2005; Rasmussen \& Laumann, 2014; Habibzadeh \& Allahvirdiyani, 2011; Kalafat, 1996; Aydemir, 2008; Özen, 2005; Saygın, 2008; Cihangir-Çankaya, 2009; Kartal, 2013; Uçan, 2013; Tingaz \& Hazar, 2014; Tunçkol, 2015). It is seen that women and men express a higher level of happiness than each other at different periods in life. This can be explained by the fact that gender is a variable that affects life-long perceptions in line with social roles. Depending on the cultural characteristics of the society they live in, it can be expected that there will be a difference between the genders in terms of happiness. For example, considering the cultural structure of the society we live in, more value is attributed to men, which causes men to be more advantageous in society and women to experience various difficulties. It is possible that this situation causes the expectation that the subjective well-being of men will be high.

The results of the research revealed that the subjective happiness and vitality levels of the students who do sports in a sports club are higher (Table 4). When the sports structure in Turkey is taken into account, it is seen that sports operate at the club level. In order to be at the top levels in sports life, it is necessary to do sports depending on a club. In the study, it can be said that it is an expected result that the students' subjective vitality and happiness levels are high when they are affiliated with a sports club. In the literature, they mentioned the positive effect of exercise on psychological well-being (Cramer, Nieman, \& Lee, 1991; Doğan, 2006; Szabo, 2003). In another study, Tunçkol (2015) stated that while there was no significant relationship between the happiness levels of the participants who regularly do sports, the happiness of the participants who had an athlete license increased. In another study, At1lgan (2011) stated that the mental and physical health status of the high school students who do sports under license are better. It is known that active participation in sports increases psychological self-efficacy strengthens physiological health and has a positive effect on the psychological well-being of athletes (Hidalgo et al., 2010; cited in Topuz, 2013). In the study conducted by Somoğlu et al. (2021), it was stated that students who do active sports had higher life satisfaction. As Gezer (2014) stated, the main purpose of participation in sports is to bring positive effects on the individual's health, happiness, rest, entertainment and personality.

When the sports branch variable was examined, it was found that the students interested in team sports showed higher subjective vitality and happiness (Table 5). Significant difference can be explained by the fact that students have higher happiness and vitality due to reasons 
such as experiencing more relationships in team sports, increasing shared experience, and the unity created by team spirit. Somoğlu (2016) found that the life satisfaction of the athletes who are interested in team sports is higher in his study on hearing-impaired sports students. Again, in the study of Somoğlu (2021), in which he tried to determine the sportive life satisfaction of sports high school students, he found that the sports-specific life satisfaction was higher in the athletes interested in team sports.

When the happiness and vitality levels of the sports high school students are analyzed according to the time they spend in sports, it is seen that the subjective happiness and vitality levels are higher in the students who had six or more years of sports practice (Table 6). Somoğlu (2016) found that the life satisfaction of the hearing-impaired athletes was significant in favor of the students who continued sports for a longer period of time. The fact that this result is meaningful can be explained by the fact that the individual enjoys doing sport and that it is a natural result that he spends a long time on practising and his happiness and vitality levels increase. In this present study, when the effect of the socio-economic status of the family on the happiness and vitality of the sports high school students was examined, no significant difference was found. In the literature, the relationship between income and well-being (international and individual level) is examined from different perspectives (Diener \& Biswas-Diener, 2002; Suh, Diener, \& Fujita, 1996). People residing in developed societies report being happier; however, when it is considered from the perspective of people living in the same country, it is stated that the difference between the groups is not so evident (Diener, 1984). In parallel with the results of the research (Nur-Şahin, 2011; Ben-Zur, 2003; Tunçkol, 2015), no significant difference could be found between socio-economic status and subjective happiness. Contrary to the research result, certain studies found significant relation between economic status and happiness (Blanchflower \& Oswald, 2005; Cummins, 2000; Paolini, Yanez, \& Kelly, 2006; Canbay, 2010; Özgür, Babacan-Gümüş, \& Durdu, 2010; Kermen, 2013; Sacks, Stevenson, \& Justin, 2010; Tuzgöl-Dost, 2004; Yazıc1, Caz, \& Tunçkol, 2016).

When the correlation and regression findings were examined in the study, it was found that there was a high level of positive correlation between vitality and happiness, and $66 \%$ of their happiness was explained by being fit. There are studies with different study groups that found a significant positive relationship between subjective happiness and vitality (Tunçkol, 2015; Köse et al., 2019; Ryan \& Frederick, 1997; Yazıcı \& Tunçkol, 2015). The fact that subjective happiness has a positive relationship with many psychologically functional variables such as psychological health, life satisfaction, positive affectivity and subjective vitality has a positive relationship with life satisfaction, self-actualization, positive affectivity, self-esteem, extroversion and intrinsic motivation shows that subjective vitality contributes positively to subjective happiness (Akın \& Akın, 2015). According to the research findings of Tunçkol (2015), there is a positive, moderate relationship between subjective vitality and happiness, and the participants' vitality levels predict $20 \%$ of their happiness levels. This result shows that there is an inseparable link between vitality and happiness, and if one increases, the other will follow it in parallel. A. Akın and Ü. Akın (2015) also found that there was a positive relationship between subjective happiness and subjective vitality, and that subjective 
happiness was positively predicted by subjective vitality. In addition, the fact that subjective vitality is positively related to a number of psychologically functional variables such as life satisfaction, self-actualization, positive affect, self-esteem, extraversion and intrinsic motivation (Ryan \& Frederick, 1997) explains the positive contribution of subjective vitality to subjective happiness.

\section{Conclusion}

It is safe to state that the students at the sports high school feel fit and happy. It has been concluded that the subjective happiness and vitality levels of the students are higher in those who are involved in sports for a longer period and who are affiliated with a sports club. In addition, it has been determined that male students are happier and fitter than female students, and team athletes are happier and more energetic than individual athletes. Therefore, it is important for all families to be interested in a sport, to participate in sports actively and regularly, and to direct their children to sportive activities. Education and sports policies should also make arrangements and organizations in this direction. Parents, teachers and administrators have a great responsibility for the participation of girls or students in sports. School administrators should see it as a mission to protect and maintain students' happiness and vitality levels. For future studies, it may be recommended to set different independent variables, increase the number of samples, or conduct experimental studies.

\section{References}

Akın, A. (2012). The relationships between Internet addiction, subjective vitality, and subjective happiness. Cyberpsychology, Behavior and Social Networking, 15(8), 404-410. https://doi.org/10.1089/cyber.2011.0609

Akın, A., \& Akın, U. (2015). Friendship quality and subjective happiness: The mediating role of subjective vitality. Education and Science, 40(177), 233-242. https://doi.org/10.15390/EB. 2015.3786

Akın, A., \& Satıcı, S. A. (2011). Subjective happiness scale: Validity and reliability study. Journal of Sakarya University Faculty of Education, 21, 65-77.

Akın, A., Satıcı, S. A., Arslan, S., Akın, Ü., \& Kayıs, A. R. (2012). The validity and the reliability of the Turkish version of the subjective vitality scale (SVS) (pp. 2-5). Paper Presented at the 4rd World Conference on Educational Sciences.

Aşç1, F. H. (2002). An investigation of age and gender differences in physical self-concept among Turkish late adolescents. Adolescence, 37(146), 365-371.

Atılgan, D. (2011). Investigation of the mental and physical health of the students who do sports and do not do sports in secondary schools affiliated to the Ministry of National Education (Unpublished Master's thesis, Erciyes University, Kayseri).

Aydemir, R. E. (2008). The relationship between religiosity and happiness (Early adulthood) (Unpublished Master's thesis, Ondokuz Mayıs University, Samsun). 
Baysal, S., \& Aka, Ç. İ. (2013). The use of happiness theme by brands as a marketing strategy: A research on happiness-based marketing. Journal of Social and Human Sciences, 5(1), 84-93.

Ben-Zur, H. (2003). Happy adolescents: The link between subjective well-being, internal resources and parental factors. Journal of Youth and Adolescence, 32(2), 67-79. https://doi.org/10.1023/A:1021864432505

Blanchflower, D. G., \& Oswald, A. J. (2005). Happiness and the human development index: The paradox of Australia. The Australian Economic Review, 38(3), 307-318. https://doi.org/ 10.1111/j.1467-8462.2005.00377.x

Çağır, G., \& Gürgân, U. (2010). The relationship between the problematic internet use levels of high school and university students and their perceived well-being and loneliness levels. Ballkesir University Journal of Social Sciences Institute, 13(24), 70-85. Retrieved from https://dergipark.org.tr/tr/pub/baunsobed/issue/50235/647944

Canbay, H. (2010). Examination of the relationship between the subjective well-being levels of high school students and their social skill levels (Unpublished Master's thesis, Dokuz Eylul University, Izmir).

Çelik, Ş. (2008). Examination of high school students' subjective well-being in terms of emotional intelligence (Unpublished Master's thesis, Selcuk University, Konya).

Cihangir-Çankaya, Z. (2009). Satisfaction of basic psychological needs and well-being in teacher candidates. Turkish Journal of Educational Sciences, 7(3), 691-711. Retrieved from https://dergipark.org.tr/en/pub/tebd/issue/26108/275077

Cirhinlioğlu, F. G. (2006). Relationships between shy tendency, religious orientations, self-construals and psychological well-being in university students (Unpublished Doctoral thesis, Hacettepe University, Ankara).

Cramer, S. R., Nieman, D. C., \& Lee, J. W. (1991). The effects of moderate exercisetraining on psychological well-being and mood state in women. Journal of Psychosomatic Research, 35(4-5), 437-449. https://doi.org/10.1016/0022-3999(91)90039-Q

Csikszentmihalyi, M. (2005). Flow. The science of happiness. Istanbul: HYB Publishing.

Cummins, R. A. (2000). Personal income and subjective well-being: A review. Journal of Happiness Studies, 1, 133-158. https://doi.org/10.1023/A:1010079728426

Diener, E. (1984). Subjective well-being. Psychological Bulletin, 95(3), 542-75. https://doi.org/10.1037/0033-2909.95.3.542

Diener, E., \& Biswas-Diener, R. (2002). Will money increase subjective well-being? Social Indicators Research, 57(2), 119-169. https://doi.org/10.1023/A:1014411319119

Diener, E., \& Myers, D. G. (1997). The science of happiness (Cover story). Futurist, 31(5), 3. 


\section{Macrothink

Diener, E., \& Seligman, M. E. P. (2002). Very happy people. Psychological Science, 13(1), 81-84. https://doi.org/10.1111/1467-9280.00415

Doğan, T. (2004). Examination of the well-being of university students (Unpublished Doctoral thesis, Hacettepe University, Ankara).

Doğan, T. (2006). Examination of the well-being of university students. Journal of Hacettepe University Faculty of Education, 30, 120-129. https://dergipark.org.tr/tr/pub/hunefd/issue/ $7806 / 102372$

Erkuş, A. (2009). Scientific research process for behavioral sciences. Ankara: Seçkin Publishing.

Fox, K. R. (1999). The influence of physical activity on mental well-being. Public Health Nutrition, 2(3a), 411-418. https://doi.org/10.1017/s1368980099000567

Gezer, H. (2014). Investigation of life satisfaction and burnout levels of law enforcement personnel who do and do not do sports (Malatya example) (Unpublished Master's thesis, Muğla Sitkı Koçman University, Muğla).

Gürgân, U. (2014). Examining the resilience and well-being of university students according to some variables. NWSA-Education Science, 9(1), 18-35. https://doi.org/10.12739/NWSA. 2014.9.1.1C0603

Habibzadeh, S., \& Allahvirdiyani, K. (2011). Effects of economic and non economic factors on happiness on primary school teachers and Urmia University professors. Procedia Social and Behavioral Sciences, 30, 2050-2051. https://doi.org/10.1016/j.sbspro.2011.10.397

Hoeger, W. K., \& Hoeger, S. A. (2012). Fitness and wellness. USA: Thomson Wadsworth Publishing.

Huang, H., \& Humphreys, B. R. (2012). Sports participation and happiness: Evidence from US microdata. Journal of Economic Psychology, 33(4), 776-793. https://doi.org/10.1016/ j.joep.2012.02.007

Kalafat, S. (1996). The role of automatic thoughts in depression and happiness (Unpublished Master's thesis, Ondokuz Mayıs University, Samsun).

Karasar, N. (2012). Scientific research method. Ankara: Nobel Academic Publishing.

Kartal, M. A. (2013). Subjective well-being and communication skill levels of secondary school students according to some variables (Unpublished Master's thesis, 19 May1s University, Samsun).

Kermen, U. (2013). Examination of university students' need satisfaction and subjective well-being levels in terms of some variables (Unpublished Master's thesis, Abant İzzet Baysal University, Bolu).

Kimball, M., \& Willis, R. (2006). Utility and happiness. University of Michigan.

Köse, B., Uzun, M., Özlü, K., Çelik, N., \& Erbaş, Ü. (2019). Examination of subjective 
happiness and vitality levels of students studying in sports sciences according to some variables (Ankara University Example). Kilis 7 Aralik University Journal of Physical Education and Sport Sciences, 3(2), 22-29.

Lyubomirsky, S., \& Lepper, H. (1999). A measure of subjective happiness: Preliminary reliability and construct validation. Social Indicators Research, 46, 137-155. https://doi.org/ 10.1023/A:1006824100041

Lyubomirsky, S., King, L., \& Diener, E. (2005). The benefits of frequent positive affect: Does happiness lead to success? Psychological Bulletin, 131(6), 803-855. https://doi.org/10.1037/ 0033-2909.131.6.803

Lyubomirsky, S., Sheldon, K. M., \& Schkade, D. (2005). Pursuing happiness: The architecture of sustainable change. Review of General Psychology, 9(2), 111-131. https://doi.org/10.1037/1089-2680.9.2.111

Mahon, N. E., Yarcheski, A., \& Yarcheski, T. J. (2005). Happiness as related to gender and health in early adolescents. Clinical Nursing Research, 14(2), 175-190. https://doi.org/ $10.1177 / 1054773804271936$

Nur-Şahin, G. (2011). Comparison of university students' self-disclosure, subjective well-being and perceived social support levels (Unpublished Master's thesis, Dokuz Eylul University, Izmir).

Özen, Ö. (2005). Subjective well-being levels of adolescents (Unpublished Master's thesis, Hacettepe University, Ankara).

Özgür, G., Babacan-Gümüş, A., \& Durdu, B. (2010). Life satisfaction of university students staying at home and dormitory. Journal of Psychiatric Nursing, 1(1), 25-3.

Paolini, L., Yanez, A. P., \& Kelly, W. E. (2006). An examination of worry and life satisfaction among college students. Individual Differences Research, 4(5), 331-339.

Rasmussen, M., \& Laumann, K. (2014). The role of exerciseduring adolescence on adult happiness and mood. Leisure Studies, 33(4), 341-356. https://doi.org/10.1080/02614367.2013. 798347

Rejeski, W. J., Shelton, B., Miller, M., Dunn, A. L., King, A. C., \& Salls, J. F. (2001). Mediators of increased physical activity and change in subjective well-being: results from activity counseling trial. Journal of Health Psychology, 6(2), 159-168. https://doi.org/ $10.1177 / 135910530100600206$

Ryan, R. M., \& Frederick, C. (1997). On energy, personality and health: Subjective vitality as a dynamic reflection of well-being. Journal of Personality, 65(3), 529-565. https://doi.org/ 10.1111/j.1467-6494.1997.tb00326.x

Sacks, D. W., Stevenson, B., \& Wolfers, J. (2010). Subjective well-being, income, economic development and growth. National Bureau of Economic Research, 16441, 1-32. https://doi.org/10.3386/W16441 


\section{Macrothink

Saygın, Y. (2008). Investigation of university students' social support, self-esteem and subjective well-being levels (Unpublished Master's thesis, Selcuk University, Konya).

Sezer, F. (2011). In H. E. Dinçer (Ed.), Examining the subjective well-being of secondary school students in terms of some variables (pp. 74-85). Ankara: Ministry of National Education Publications.

Şimşek, H., \& Yıldırım, A. (2004). Qualitative research methods in the social sciences. Ankara: Seçkin Publishing.

Somoğlu, M. B. (2016). Investigation of perceived social support levels and life satisfaction of hearing-impaired students according to their athletic status (Unpublished Master's thesis. Karadeniz Technical University, Institute of Educational Sciences, Trabzon).

Somoğlu, M. B., Yüksek, S., Kılıçaslan, U., \& Sivrikaya, T. (2021). Investigation of Life Satisfaction Levels of Sports High School Students (Example of Trabzon Province). In M. Ilkım, \& M. Turan (Eds.), Research and Evaluations in Sport Sciences (Volume I, pp. 53-74). Ankara: Night Library.

Suh, E., Diener, E., \& Fujita, F. (1996). Events and swb: Only recent events matter. Journal of Personality and Social Psychology, 70(5), 1091-1102. https://doi.org/10.1037/0022-3514. 70.5.1091

Szabo, A. (2003). The acute effects of humor and exercise on mood and anxiety. Journal of Leisure Research, 35(2), 152-162. https://doi.org/10.1080/00222216.2003.11949988

Taşer, H. (2004). Physical fitness training. Atatürk University BESYO Journal of Physical Education and Sport Sciences, 6(3), 48-55.

Tingaz, E. O., \& Hazar, M. (2014). Comparison of physical education and sports teaching and emotional intelligence and happiness of some teacher candidates. International Journal of Science Culture and Sport, SP 1, 745-756. https://doi.org/10.14486/IJSCS144

Topuz, C. (2013). Examining the relationship of altruism with subjective well-being and psychological well-being in university students (Unpublished Master's thesis, Fatih University, Istanbul).

Tunçkol, H. M. (2015). Relationship of happiness and subjective vitality in university students. International Journal of Development Research, 5(4), 4219-4222.

Türkdoğan, T. (2010). The role of the level of meeting basic needs in predicting subjective well-being of university students (Unpublished Master's thesis, Pamukkale University, Denizli).

Tuzgöl-Dost, M. (2004). Subjective well-being levels of university students (Unpublished Doctoral thesis, Hacettepe University, Ankara).

Tuzgöl-Dost, M. (2006). Subjective well-being levels of university students. Journal of Hacettepe University Faculty of Education, 31, 188-197. 


\section{Macrothink

Uçan, A. (2013). Examination of the subjective well-being of high school students of different genders according to risk taking and migration variables related to social position (Unpublished Master's thesis, Mersin University, Mersin).

Yalçın, M. (1994). The path and philosophy of happiness. Istanbul: Scientific Publications.

Yazıcı, Ö. F., \& Tunçkol, H. M. (2015). Examination of happiness and vitality levels of physical education teacher candidates (Unpublished Master's thesis. Karadeniz Technical University, Institute of Educational Sciences, Trabzon).

Yazıcı, Ö. F., Caz, Ç., \&Tunçkol, H. M. (2016). Subjective happiness levels of staff working in provincial organization of general directorate of sport. International Journal of Sports, Exerciseand Training Science, 2(1), 125-131. https://doi.org/10.18826/ijsets.02669

Yetim, Ü. (2001). Pictures of happiness from society to individual. İstanbul: Bağlam Publications.

\section{Copyright Disclaimer}

Copyright for this article is retained by the author(s), with first publication rights granted to the journal.

This is an open-access article distributed under the terms and conditions of the Creative Commons Attribution license (http://creativecommons.org/licenses/by/3.0/). 